\title{
Neutral Sterols of Cephalic Glands of Stingless Bees and Their Correlation with Sterols from Pollen
}

\author{
Maria Juliana Ferreira-Caliman, Cláudia Inês da Silva, Sidnei Mateus, \\ Ronaldo Zucchi, and Fabio Santos do Nascimento
} Departamento de Biologia, Faculdade de Filosofia, Ciências e Letras de Ribeirão Preto-FFCLRP, Universidade de São Paulo (USP),
Avenida Bandeirantes 3900, 14040-901 Ribeirão Preto, SP, Brazil

Correspondence should be addressed to Maria Juliana Ferreira-Caliman, jucaliman@hotmail.com

Received 2 August 2012; Revised 2 October 2012; Accepted 3 October 2012

Academic Editor: Kleber Del-Claro

Copyright ( $) 2012$ Maria Juliana Ferreira-Caliman et al. This is an open access article distributed under the Creative Commons Attribution License, which permits unrestricted use, distribution, and reproduction in any medium, provided the original work is properly cited.

\begin{abstract}
Sterols are essential molecules in the membrane lipid composition and precursors of important sterol hormones that regulate many developmental processes. Insects are unable to synthesize sterols de novo and, thus, all phytophagous insects depend on an exogenous source of sterols for growth, development, and reproduction. The sterol requirements of social bees are not fully known due to the fact that there is no well-defined diet available throughout the year with regard to floral resources. Our study aimed to characterize the sterols present in pollen stored in Melipona marginata and Melipona scutellaris colonies, as well as evaluating their presence in the mandibular, hypopharyngeal, and cephalic salivary gland secretions. We analyzed the chemical composition of pollen stored in the colonies and the composition of the cephalic glands of workers in three adult functional phases (newly emerged, nurses, and foragers) by gas chromatography and mass spectrometry. The results showed that the pollen analyzed contained campesterol, stigmasterol, sitosterol, isofucosterol, lanosterol, and small amounts of cholesterol. The glands showed the same compounds found in the pollen analyzed, except lanosterol that was not found in M. scutellaris glands. Surprisingly, cholesterol was found in some glands with relative ratios greater than those found in pollen.
\end{abstract}

\section{Introduction}

Sterols are essential molecules in cell membrane, they are precursors of sterol hormones and other important regulators of developmental processes. However, insects are unable to synthesize them and have to purchase sterols from their diet [1]. The dietary needs for sterols in insects were firstly reported by Hobson [2] in the blowfly Lucilia sericata. Moreover, in 1959, Clark and Bloch [3] showed the inability of insects to synthesize sterols de novo, so that they need to purchase these compounds for auxotrophy (from the Greek "to increase" and "nutrition"). Auxotrophic individuals are unable to synthesize organic compounds necessary for its growth. These authors showed the importance of sterols as structural (cholestanol) and metabolic (cholesterol) components in insects. Further studies showed that ecdysteroids derivatives from cholesterol participate in the control of insect growth and maturation [4].
Furthermore, the necessity of sterol ingestion by insects has been demonstrated in different orders including Orthoptera, Hemiptera, Diptera, Lepidoptera, and Hymenoptera [5]. Indeed, all phytophagous insects studied to date rely on exogenous sterol for growth, reproduction and development $[6,7]$. Many phytophagous insects are able to convert phytosterols in cholesterol through the dealkylation of compounds containing 28 to 29 carbon atoms, such as desmosterol, campesterol, brassicasterol, fucosterol, and sitosterol [8-10]. However, honeybees are unable to perform this conversion $[11,12]$. Other phytophagous insects that donot have the mechanism of dealkylation of phytosterols include two species of Hemiptera (Oncopeltus fasciatus, [13]; Dysdercus fasciatus, [14]) and one species of Coleoptera (Trogoderma granarium, [15]). The ability to convert phytosterols in cholesterol was not verified in other groups of bees.

The sterol requirements of bees are not assessable because their diet and pollen sources remain unknown. The main 
sterol present in the pollen of plants is 24-methylenecholesterol [16-18]. However, other studies reported that besides the 24-methylenecholesterol, the pollen presents phytosterols as desmosterol, campesterol, fucosterol, sitosterol, and even small quantities of cholesterol [17].

Steroidal compounds might be incorporated and stored in different organs of a bee. Queens and workers of honey bees have a significant amount of 24-methylenecholesterol in their body [19]. Svoboda et al. [1] showed that the 24methylenecholesterol, isofuscosterol, sitosterol, and campesterol are present in hypopharyngeal and in mandibular glands of honeybee nurses. The size of cephalic glands (mandibular, hypopharyngeal, and labial) in eusocial bees vary according to the age of individuals [20]. In Apis mellifera, the mandibular and the hypopharyngeal glands reach a higher peak of development in nurse bees and they are related with food supply to larvae [20]. We hypothesized that, like in Apis mellifera, the cephalic glands of stingless bees play a role as storage organs of phytosterols. Our study aimed to characterize the sterols present in pollen stored in Melipona marginata and M. scutellaris colonies, as well as to evaluate their presence in the mandibular, hypopharyngeal, and cephalic salivary gland secretions.

\section{Material and Methods}

We used two colonies of Brazilian stingless bee species: Melipona marginata and Melipona scutellaris. The colonies were kept at the meliponary of Universidade de São Paulo, Ribeirão Preto. For each species, we collected 10 newly emerged workers, 10 nursing workers, 10 foragers, and two samples $(1 \mathrm{~g})$ of pollen storage in pots, all on the same day. We marked the new cells produced in the comb that day for later collection of newly emerged workers. The mandibular (MAN), hypopharyngeal (HYP), and labial glands (LAB) (cephalic section) were dissected under stereomicroscope and put individually in $30 \mu \mathrm{L}$ of hexane. The pollen samples were put in methanol $(4 \mathrm{~mL} / 1 \mathrm{~g})$ and the extracts were centrifuged (for removal the proteins). The aqueous phase was removed and dried under $\mathrm{N}_{2}$ and resuspended in $400 \mathrm{~mL}$ of hexane. The samples were injected in a combined gas chromatography-mass spectrometry (GC-MS: SHIMADZU, model QP2010). Separation was achieved on a DB-5MS column $30 \mathrm{~m}$, and the gas carrier was helium at $1.0 \mathrm{~mL}$ $\mathrm{min}^{-1}$. The oven temperature was initially set to $50^{\circ} \mathrm{C}$ (held for $1 \mathrm{~min}$ ) and increased by $10^{\circ} \mathrm{C} \mathrm{min}^{-1}$ until it reached $300^{\circ} \mathrm{C}$ (held for $15 \mathrm{~min}$ ). Analyses were performed in splitless mode. The mass spectra were obtained by $70 \mathrm{eV}$ ionization. The data were analyzed with GCMS solutions for Windows (Shimadzu Corporation), and the chemical compounds were identified based on their mass spectra by comparison with Nist Library data and with a standard solution of different synthetic phytosterols (Sigma-Aldrich).

We analyzed the pollen as described in Silva et al. [21]. The protein fractions of pollen were kept in alcohol 70\% and after 24 hours the alcohol was discarded. The samples were placed in vials containing $4 \mathrm{~mL}$ of absolute glacial acetic acid ( 24 hours) according to the acetolysis protocol described by
Erdtman [22]. Following acetolysis, the pollen was placed on slides for light microscopy with 50\% glycerin. We identified pollen types by comparison with pollen grains deposited on Palinoteca of Faculdade de Filosofia, Ciências e Letras de Ribeirão Preto, Universidade de São Paulo, using a Leica DM $4000 \mathrm{~B}$ microscope, with an increase of up to $2.560 \mathrm{x}$.

\section{Results}

Results of sterol analyses of pollen, hypopharyngeal glands (HYP), labial glands (LAB), and mandibular glands (MAN) of Melipona marginata and Melipona scutellaris are summarized in Tables 1 and 2. The pollen samples collected in pots of the two Melipona species showed the same ratios of cholesterol, campesterol, stigmasterol, sitosterol, isofucosterol, and lanosterol. In general, the gland secretions showed the same sterols as pollen, with some variations according to the age of workers and the gland type. The only exception was the absence of lanosterol in the glands of $M$. scutellaris bees, even though it is present in pollen collected in pots. In M. marginata, sitosterol was the main sterol present in pollen and glands (except for the mandibular glands of nurse bees) while in M. scutellaris campesterol and sitosterol had the highest proportions. Cholesterol in pollen samples had lower relative percentage $(0.53 \%$ and $0.33 \%)$ than others sterols. There was no pattern of increasing or decreasing of the relative percentages of phytosterols present in glands in relation to the age of individuals. The sterols were obtained from Angiosperms as Arecaceae (M. scutellaris, 1 species), Fabaceae (M. marginata, 4 species; M. scutellaris, 3 species), Melastomataceae (M. marginata, 1 species) and Myrtaceae (M. marginata, 1 species; M. scutellaris, 3 species), according to pollen type (Table 3 ).

3.1. Newly Emerged Workers. The main sterol found in $M$. marginata glands was sitosterol, followed by cholesterol (HYP and LAB) and isofucosterol (MAN). In M. scutellaris glands, the main compounds were sitosterol (HYP and MAN) and campesterol (LAB) followed by isofucoterol (HYP) and cholesterol (MAN). In M. marginata workers, stigmasterol was found only in mandibular glands and lanosterol was found in mandibular and hypopharyngeal glands. The hypopharyngeal gland and the labial gland of newly emerged workers showed a higher proportion of cholesterol when compared with the pollen in M. marginata (26.62\%, $47.7 \%$ and $0.53 \%$, resp.). In M. scutellaris, all glands of newly emerged workers showed a higher percentage of cholesterol when compared with pollen (HYP $=11.20 \%$, $\mathrm{MAN}=19.96 \%, \mathrm{LAB}=20.79 \%$, and Pollen $=0.33 \%)$.

3.2. Nurse Workers. Sitosterol was the main steroidal compound found in the glands of nurse bees, except for mandibular glands of M. marginata (stigmasterol) and hypopharyngeal glands in $M$. scutellaris (campesterol). Campesterol was the second major sterol found in this class of workers (HYP and MAN in M. marginata, MAN in M. scutellaris). Only the labial gland of M. scutellaris showed isofucosterol as the second main compound. In M. marginata, the glands of 


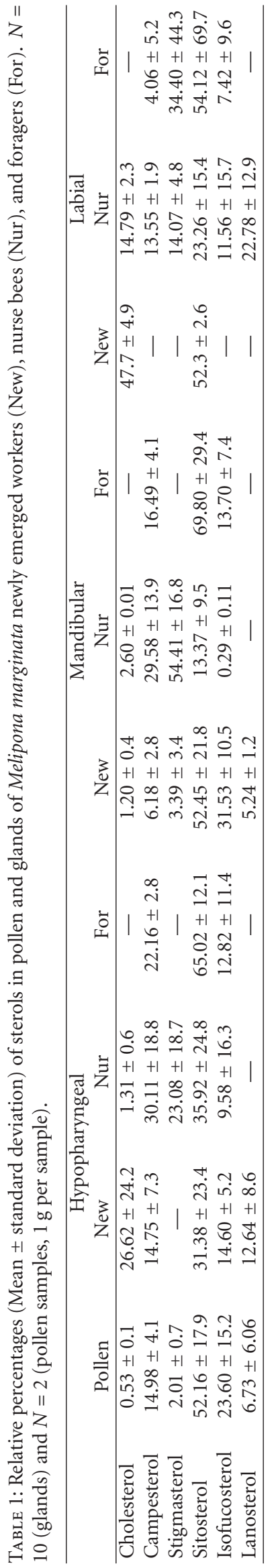




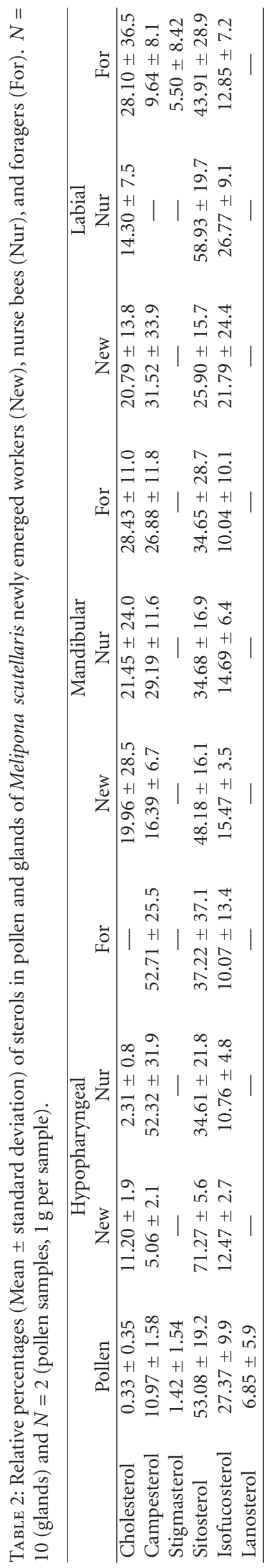


TABLE 3: Pollen types found in food pots of Melipona marginata and Melipona scutellaris colonies.

\begin{tabular}{|c|c|c|}
\hline Families/species & M. marginata & M. scutellaris \\
\hline \multicolumn{3}{|l|}{ Arecaceae } \\
\hline $\begin{array}{l}\text { Archontophoenix alexandrae } \\
\text { (F. Muell.) H. Wendl. and Drude }\end{array}$ & - & + \\
\hline \multicolumn{3}{|l|}{ Fabaceae } \\
\hline $\begin{array}{l}\text { Anadenanthera macrocarpa } \\
\text { (Benth.) Brenan }\end{array}$ & + & + \\
\hline $\begin{array}{l}\text { Anadenanthera peregrina (L.) } \\
\text { Speg. }\end{array}$ & + & + \\
\hline $\begin{array}{l}\text { Leucaena leucocephala (Lam.) } \\
\text { de Wit }\end{array}$ & - & + \\
\hline Mimosa sp. & + & - \\
\hline $\begin{array}{l}\text { Senna macranthera } \\
\text { (DC. ex Collad.) H. S. Irwin and } \\
\text { Barneby }\end{array}$ & + & - \\
\hline \multicolumn{3}{|l|}{ Melastomataceae } \\
\hline $\begin{array}{l}\text { Tibouchina granulosa (Desr.) } \\
\text { Cogn. }\end{array}$ & + & - \\
\hline \multicolumn{3}{|l|}{ Myrtaceae } \\
\hline $\begin{array}{l}\text { Eucalyptus grandis W. Mill } \\
\text { ex Maiden }\end{array}$ & + & - \\
\hline Eucalyptus moluccana Roxb. & - & + \\
\hline Eugenia involucrata DC. & - & + \\
\hline Eugenia pyriformis Cambess. & - & + \\
\hline
\end{tabular}

Presence: (+) and absence: (-).

nurse bees showed a higher proportion of stigmasterol when compared with pollen $(\mathrm{HYP}=23.08, \mathrm{MAN}=54.41 \%, \mathrm{LAB}=$ $14.07 \%$, and Pollen $=2.01 \%$ ). In M. scutellaris, all glands of nurse bees showed a higher relative proportion of cholesterol when compared with pollen $(\mathrm{HYP}=2.31 \%, \mathrm{MAN}=20.43 \%$, $\mathrm{LAB}=14.30 \%$, and Pollen $=0.33 \%)$.

3.3. Forager Workers. Cholesterol and lanosterol were absent in M. marginata forager workers. Stigmasterol was present only in labial glands of the two analyzed species. M. scutellaris also lacked lanosterol, and sitosterol was the main compound found in the glands, except for hypopharyngeal glands (campesterol). M. marginata forager workers showed great relative amounts of campesterol and cholesterol in HYP and MAN gland secretions, and M. scutellaris workers presented higher relative concentrations of these same compounds in MAN and LAB glands secretions. In M. marginata, the glands of foragers showed a higher proportion of stigmasterol when compared with pollen $(\mathrm{LAB}=34.40 \%$ and Pollen $=2.01 \%)$. Mandibular glands and labial glands of $M$. scutellaris foragers showed a higher percentage of cholesterol when compared with pollen $(\mathrm{MAN}=28.43 \%, \mathrm{LAB}=28.10 \%$, and Pollen $=$ $0.33 \%)$.

\section{Discussion}

This study shows that once sterols are ingested they are distributed among different glands of two stingless bee species. As phytosterols play an important role in sterol metabolism and ecdysteroid production [8, 10, 23-26], the ingestion of exogenous sterols is essential for structural and metabolic components. Sterols seem to be absorbed mainly in the midgut, particularly in phytophagous species [27, 28], moving quickly through mucosal cells [28].

The analyzed pollen and glands lacked 24-methylenecholesterol, differently from results found for Apis mellifera by Svoboda et al. [1]. The pollen samples collected in pots of the two Melipona species showed the same ratios of sterols despite the differences in pollen origin. Patterson [29] showed that the most abundant sterols found in Angiosperms were sitosterol and stigmasterol, but many species also contain campesterol and dihydrobrassicasterol. The pollen of most plant species accumulate intermediates such as 24-methylenecholesterol and 9 $\beta, 19$-cyclopropyl sterols [30]. However, sitosterol can be the main sterol in some species, as found in Baccharis viminea, Juniperus uthaensis, Polygonum sp., Hydrophyllum capitatum, Pinus sylvestris, and other plants [31]. Large amounts of stigmasterol and cholesterol were found in the pollen of heather (Calluna vulgaris) and in cottonwood (Populus fremontii), respectively.

Among bees, 24-methylenecholesterol is the main sterol available in natural diet and the dominant tissue sterol, followed by other phytosterols according to the bee's hostplants [32]. We showed in our study that the main sterols of pollen were present in glands. Moreover, despite the inability of some stingless bees of dealkylation of phytosterols into cholesterol, we found large amounts of cholesterol in some glands. Indeed, the Apocrita (Hymenoptera) lost the dealkylation ability [32], and bees use several unmetabolized sterols. Thus, the accumulation of cholesterol in their glands remains unexplained.

One of the most probable hypotheses to explain the tissue accumulation of sterols is the selective transfer of sterols from the adults' endogenous pools to the offspring [1]. Svoboda et al. [1] showed that sterols of the workers could be transferred to the developing larvae through the brood food material secreted from the hypopharyngeal and mandibular glands and/or the honey stomach of the workers. Tissue sterol profiles can differ between males and females. Female's reproductive organs have higher concentration of cholesterol in Eurycotis floridana [33] and queen ovaries of Apis mellifera have higher concentrations of 24-methylenecholesterol, campesterol, and sitosterol [34]. Regarding development, sterol profile is influenced by the stage of development (egg, larva and adult) in ants, and the eggs presented the lowest diversity in types of sterol, while the queen had the highest [35].

Relative concentrations in secretions of workers of the same group have high deviations, but this can be explained by the differences in the age of the worker performing a task in colonies of social bees. Ferreira-Caliman et al. [36] showed that engagement in tasks on brood comb (nurse bees) 
occurred between 5 th and 12 th days postemergence and the foraging activities initiated after 22 days postemergence and this task can be observed at least for 30 days.

This study is the first report on the participation of cephalic glands as storage tissues of pollen phytosterols in stingless bees. We could not assess how the accumulation of phytosterols occurs throughout life of the individual, because no bioassay using a controlled diet was performed. However, we showed that the glands of the head of stingless bees are an important storage tissues for these compounds, although many studies are still needed to understand how this transfer occurs and the role of these glands as reservoirs of sterols.

\section{Conflict of Interests}

The authors declare that there was no conflict of interests or any research financial gain concerning the results of the present study.

\section{Acknowledgments}

This study was supported by Coordenação de Aperfeiçoamento de Pessoal de Nível Superior (CAPES; for scholarship provided to M. J. Ferreira-Caliman and for PNPD Process no. 2288/2009 provided to C. I. Silva) and Fundação de Amparo à Pesquisa do Estado de São Paulo (Fapesp; no. 10/100275 and no. 2010/10285-4). The authors are thankful for the linguistic revision made by Larissa G. Elias. The authors also thank the graduate students Kátia P. Aleixo and Letícia B. de Faria who prepared the pollen slides.

\section{References}

[1] J. A. Svoboda, E. W. Herbert, M. J. Thompson, and M. F. Feldlaufer, "Selective sterol transfer in the honey bee: Its significance and relationship to other hymenoptera," Lipids, vol. 21, no. 1, pp. 97-101, 1986.

[2] R. P. Hobson, "CCXXXVI. On a fat-soluble growth factor required by blow-fly larvae II. Identity of the growth factor with cholesterol," Journal of Biochemistry, vol. 29, pp. 20232026, 1935.

[3] A. J. Clark and K. Bloch, "Function of sterols in Dermestes vulpinus," The Journal of Biological Chemistry, vol. 234, pp. 2583-2588, 1959.

[4] L. I. Gilbert, R. Rybczynski, and J. T. Warren, "Control and biochemical nature of the ecdysteroidogenic pathway," Annual Review of Entomology, vol. 47, pp. 883-916, 2002.

[5] J. A. Svoboda, M. F. Feldhaufer, and G. F. Weirich, "Evolutionary aspects of steroid utilization in insects," ACS Symposyum Series, vol. 562, pp. 126-139, 1994.

[6] W. B. Heed and H. W. Kircher, "Unique sterol in the ecology and nutrition of Drosophila pachea," Science, vol. 149, no. 3685, pp. 758-761, 1965.

[7] H. M. Chu, D. M. Norris, and L. T. Kok, "Pupation requirement of the beetle, Xyleborus ferrugineus: sterols other than cholesterol," Journal of Insect Physiology, vol. 16, no. 7, pp. 1379-1387, 1970.

[8] M. J. Thompson, J. N. Kaplanis, W. E. Robbins, and J. A. Svoboda, "Metabolism of steroids in insects," Advances in Lipid Research, vol. 11, pp. 219-265, 1973.
[9] J. A. Svoboda, J. N. Kaplanis, W. E. Robbins, and M. J. Thompson, "Recent developments in insect steroid metabolism," Annual Review of Entomology, vol. 20, pp. 205-220, 1975.

[10] J. A. Svoboda, M. J. Thompson, W. E. Robbins, and J. N. Kaplanis, "Insect steroid metabolism," Lipids, vol. 13, no. 10, pp. 742-753, 1978.

[11] J. A. Svoboda, E. W. Herbert Jr., M. J. Thompson, and H. Shimanuki, "The fate of radiolabelled $\mathrm{C}_{28}$ and $\mathrm{C}_{29}$ phytosterols in the honey bee," Journal of Insect Physiology, vol. 27, no. 3, pp. 183-188, 1981.

[12] J. A. Svoboda, E. W. Herbert Jr., and M. J. Thompson, "Definitive evidence for lack of phytosterol dealkylation in honey bees," Experientia, vol. 39, no. 10, pp. 1120-1121, 1983.

[13] J. A. Svoboda, S. R. Dutky, W. E. Robbins, and J. N. Kaplanis, "Sterol composition and phytosterol utilization and metabolism in the milkweed bug," Lipids, vol. 12, no. 3, pp. 318-321, 1977.

[14] J. M. Gibson, M. S. I. Majumder, A. H. W. Mendis, and H. H. Rees, "Absence of phytosterol dealkylation and identification of the major ecdysteroid as makisterone A in Dysdercus Jascialus (Heteroptera, Pyrrhocoridae)," Archives of Insect Biochemistry and Physiology, vol. 105, p. 120, 1983.

[15] J. A. Svoboda, A. M. G. Nair, N. Agarwal, and W. E. Robbins, "Lack of conversion of $\mathrm{C}_{29}$-phytosterols to cholesterol in the khapra beetle, Trogoderma granarium Everts," Experientia, vol. 36, no. 9, pp. 1029-1030, 1980.

[16] M. Barbier, M. F. Hügel, and E. Lederer, "Isolation of 24methylene cholesterol from the pollen of different plants," Bulletin de la Société de Chimie Biologique, vol. 42, pp. 91-97, 1960.

[17] M. F. Hügel, “Sur les stérols du pollen,” Annual Abeille, vol. 8, pp. 309-315, 1965.

[18] L. N. Standifer, M. Devys, and M. Barbier, "Pollen sterols-a mass spectrographic survey," Phytochemistry, vol. 7, no. 8, pp. 1361-1365, 1968.

[19] M. Barbier and O. Schindler, "lsolicrung xon 24-methylencholesterin aus Königinnen und Arbeiterinnen der Honigbiene (Apis mellifera L.)," Helvetica Chimica Acta, vol. 42, pp. 19982005, 1959.

[20] C. Cruz-Landim, Abelhas: Morfologia e Função de Sistemas, Editora Unesp, São Paulo, Brazil, 2009.

[21] C. I. Silva, P. L. O. Ballesteros, M. A. Palmero, S. G. Bauermann, A. C. P. Evaldt, and P. E. Oliveira, Catálogo Polínico: Palinologia Aplicada em Estudos de Conservação de Abelhas do Gênero Xylocopa no Triângulo Mineiro, EDUFU, Uberlândia, Brazil, 2010.

[22] G. Erdtman, Handbook of Palynology: Morphology, Taxonomy, Ecology: an Introduction to the Study of Pollen Grains and Spores, Hafner Publishing, New York, NY, USA, 1969.

[23] J. A. Svoboda and M. J. Thompson, "Steroids," in Comprehensive Insect Physiology, Biochemistry and Pharmacology, G. A. Kerkut and L. I. Gilbert, Eds., vol. 10, pp. 137-175, Pergamon Press, Elmsford, NY, USA, 1985.

[24] J. A. Svoboda and M. F. Feldlaufer, "Neutral sterol metabolism in insects," Lipids, vol. 26, no. 8, pp. 614-618, 1991.

[25] N. Ikekawa, M. Morisaki, and Y. Fujimoto, "Sterol metabolism in insects: dealkylation of phytosterol to cholesterol," Accounts of Chemical Research, vol. 26, no. 4, pp. 139-146, 1993.

[26] J. A. Svoboda, "Variability of metabolism and function of sterols in insects," Critical Reviews in Biochemistry and Molecular Biology, vol. 34, no. 1, pp. 49-57, 1999.

[27] M. Joshi and H. C. Agarwal, "Site of cholesterol absorption in some insects," Journal of Insect Physiology, vol. 23, no. 3, pp. 403-404, 1977. 
[28] Z. E. Jouni, J. Zamora, and M. A. Wells, "Absorption and tissue distribution of cholesterol in Manduca sexta," Archives of Insect Biochemistry and Physiology, vol. 49, no. 3, pp. 167-175, 2002.

[29] G. W. Patterson, "Phylogenetic distribution of sterols", in Isopentenoids and Other Natural Products: Evolution and Function, W. D. Nes, Ed., pp. 91-107, American Chemical Society, Washington, DC, USA, 1994.

[30] W. D. Nes and J. O. Schmidt, "Isolation of 25(27)dehydrolanost-8-enol from Cereus giganteus and its biosynthetic implications," Phytochemistry, vol. 27, no. 6, pp. 1705$1708,1988$.

[31] L. N. Standifer, M. Devys, and M. Barbier, "Pollen sterols-a mass spectrographic survey," Phytochemistry, vol. 7, no. 8, pp. 1361-1365, 1968.

[32] S. T. Behmer and W. D. Nes, "Insect sterol nutrition and physiology: a global overview," Advances in Insect Physiology, vol. 31, pp. 1-72, 2003.

[33] N. L. Lasser, A. M. Edwards, and R. B. Clayton, "Distribution and dynamic state of sterols and steroids in the tissues of an insect, the roach Eurycotis floridana," Journal of Lipid Research, vol. 7, no. 3, pp. 403-412, 1966.

[34] M. F. Feldlaufer, J. A. Svoboda, and E. W. Herbert Jr., "Makisterone A and 24-methylenecholesterol from the ovaries of the honey bee, Apis mellifera L," Experientia, vol. 42, no. 2, pp. 200-201, 1986.

[35] A. Ba, D. Guo, R. A. Norton, S. A. Phillips, and W. D. Nes, "Developmental differences in the sterol composition of Solenopsis invicta," Archives of Insect Biochemistry and Physiology, vol. 29, pp. 1-9, 1995.

[36] M. J. Ferreira-Caliman, F. S. Nascimento, I. C. Turatti, S. Mateus, N. P. Lopes, and R. Zucchi, "The cuticular hydrocarbons profiles in the stingless bee Melipona marginata reflect task-related differences," Journal of Insect Physiology, vol. 56, no. 7, pp. 800-804, 2010. 

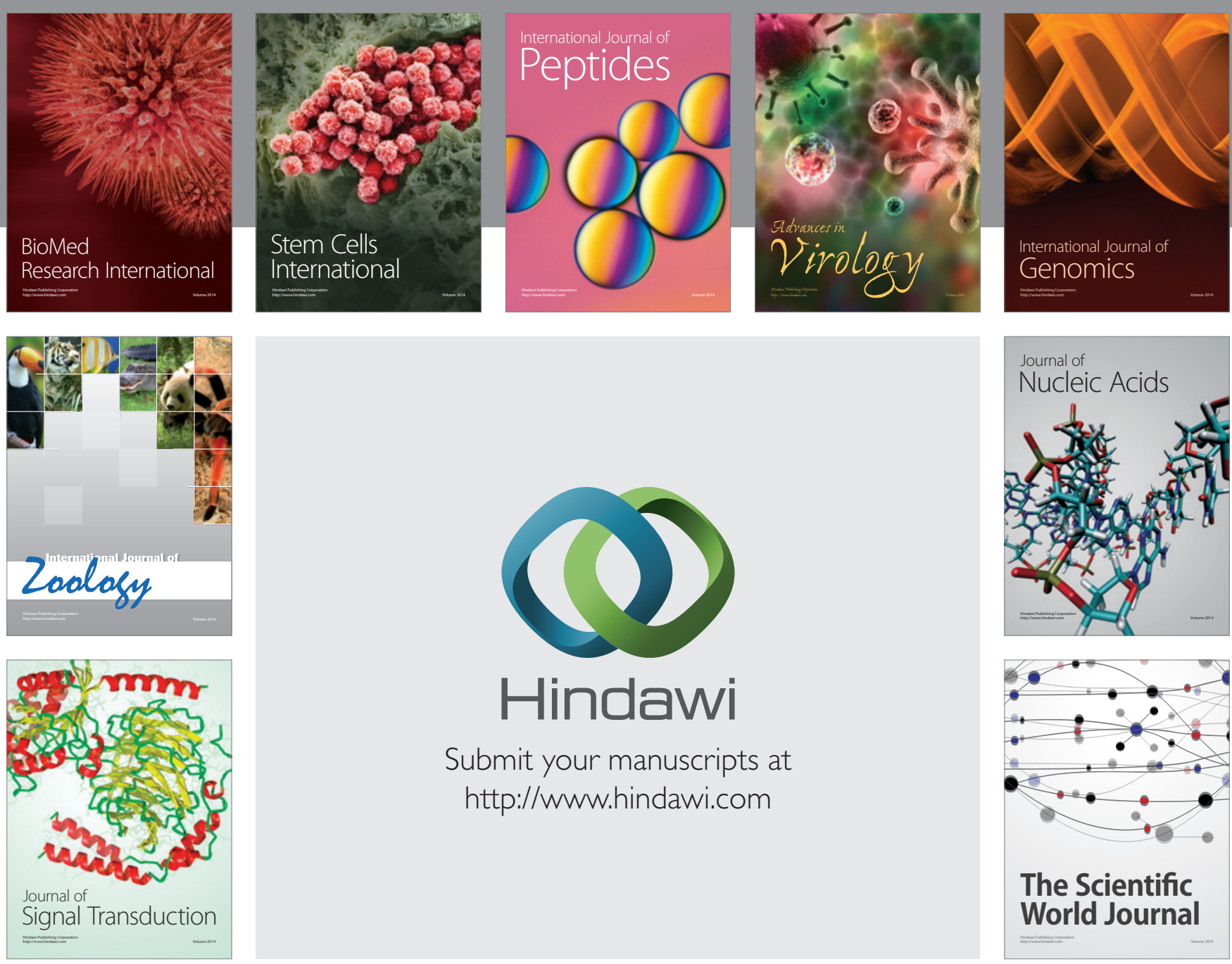

Submit your manuscripts at

http://www.hindawi.com
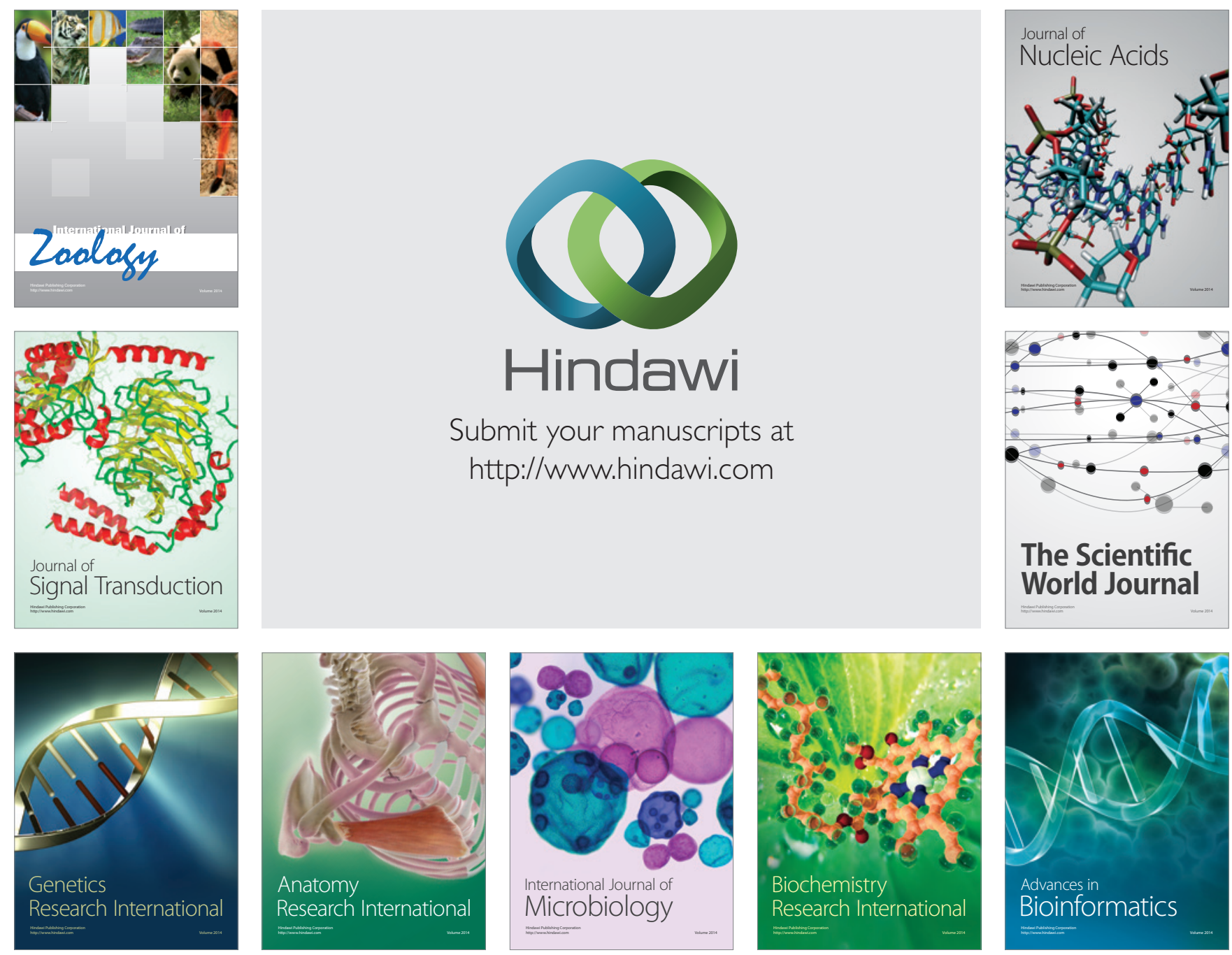

The Scientific World Journal
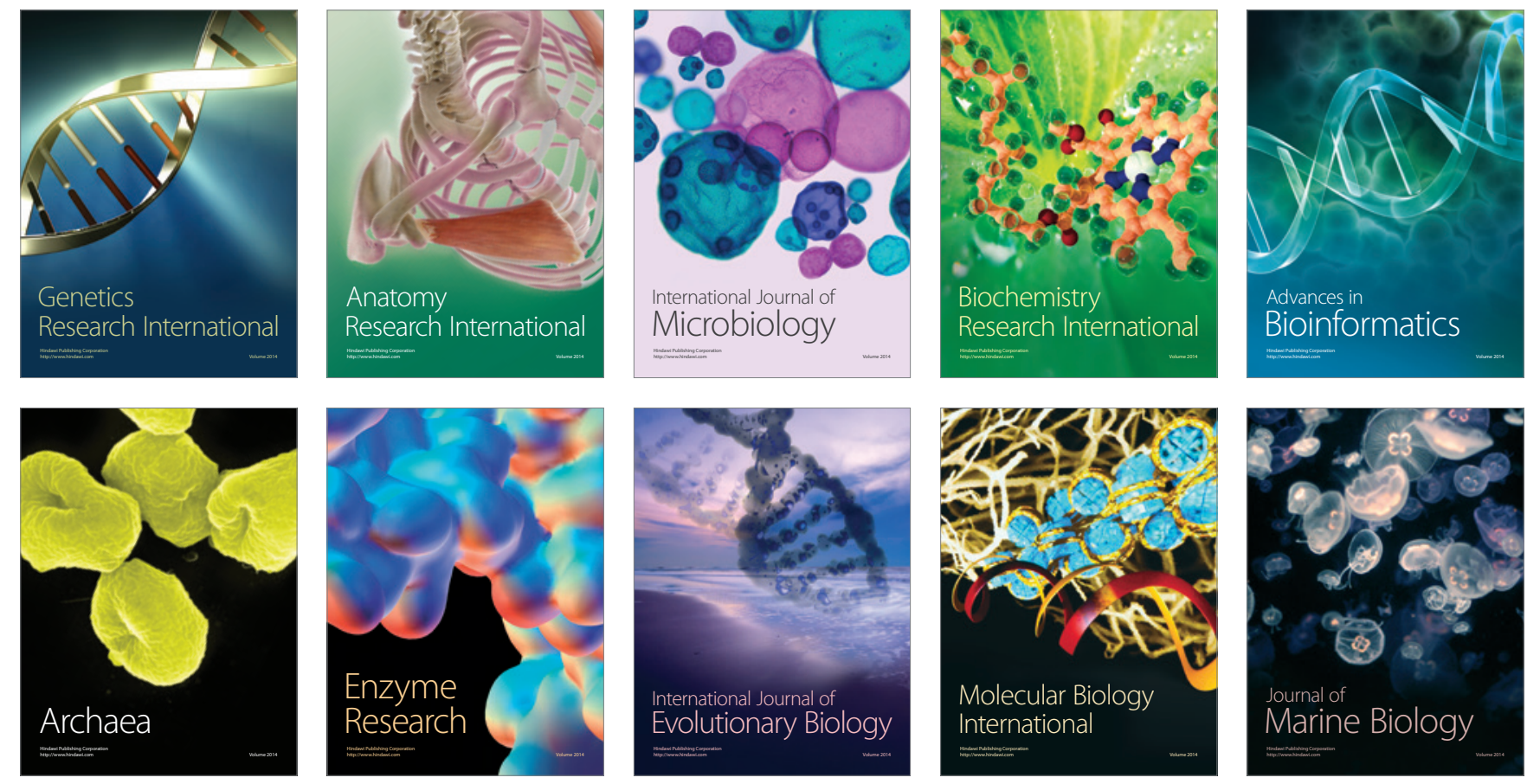